\title{
Konstruksi profesionalisme aparat: Dukungan pimpinan dan perbaikan kesejahteraan
}

\section{Construction of employees profesionalism: The supervisor support and prosperity improvement}

\author{
Bintoro Wardiyanto ${ }^{1}$, dan Dwi Windyastuti Budi Hendrati ${ }^{2}$ \\ 1) Departemen Administrasi Negara, FISIP, Universitas Airlangga, Surabaya \\ 2) Departemen Ilmu Politik, FISIP, Universitas Airlangga, Surabaya \\ Jalan Airlangga 4-6 Surabaya 60286, Indonesia. Telepon: +62 315011744 \\ E-mail: bintorowardiyanto@yahoo.com
}

\begin{abstract}
Capacity-building employees has become a global policy instrument in the New Public Management perspective to create the organization's effectiveness and efficiency in the bureaucracy. The release of the State Civil Administrative Law has strengthened efforts to establish the capacity of the officials who are competent and professional. This research uses purposive sampling technique. Respondent were choosen from Food Security Office and Archive and Library Office in 4 areas, namely Bojonegoro, Kapas, Balen, and Dander. In line with the results of the study, it appears that the construction capabilities of the apparatus has a high chance to realize the vision and mission of the new district. In addition, capacitybuilding apparatus in an area determined by the area of leadership role models, the regent than on education leadership. Professionalism apparatus constructed as a positive energy that is not only related to the knowledge and expertise as well as the achievement of an individual's performance, but is highly dependent on the creation of a conducive environment for professionalism itself, such as the feasibility of welfare officials, the clarity of sanctions and rewards as well as encouragement and ethos work.
\end{abstract}

Keywords: competence, professional apparatus, local leadership support.

\begin{abstract}
Abstrak
Pengembangan kapasitas pekerja telah menjadi kebijakan instrumen global pada perspektif manajemen publik baru untuk menciptakan efektiivitas dan efisiensi dalam birokrasi pemerintah. Penerbitan hukum administrasi sipil negara telah menguatkan upaya untuk menciptakan kapasitas pegawai yang kompeten dan profesional. Penelitian ini menggunakan menetapkan sampel penelitian secara purposive. Responden diambil dari Kantor Ketahan pangan dan Kantor Arsip dan Perpustakaan, dan yang mewakili Kecamatan ada 4 Kecamatan, yakni Kecamatan Bojonegoro, Kapas, Balen dan Dander. Penelitian ini menyimpulkan bahwa konstruksi kapabilitas aparat memiliki peluang tinggi untuk menrealisasikan visi dan misi di daerah. Lebih lanjut, pengembangan kapasitas aparat di area tertentu ditentukan oleh model kepemimpinan, wilayah, serta latar belakang pendidikan pemimpin. Aparat yang profesional terkonstruksi sebagai energi positif dalam performa individu, namun tidak dapat dipisahkan dari lingkungan profesional yang kondusif, antara lain seperti kesejahteraan pegawai yang layak, kejelasan sanksi jika pegawai melakukan kesalahan, serta pemberian imbalan dan dorongan pada pegawai dengan etos kerja yang baik.
\end{abstract}

Kata kunci: kompetensi, aparat profesional, dukungan pemimpin lokal

\section{Pendahuluan}

Hakikat aparat birokrasi sebagai manusia bukan lagi ditempatkan sebagai objek ataupun penerima dari proses perubahan, namun harus mampu ditempatkan sebagai subjek yang berperan aktif dalam setiap tahapan proses rekayasa perubahan modernitas birokrasi itu sendiri.

Secara filosofis, eksistensi aparatur sipil negara tidak sekedar hanya menjalani hidup dan terbelenggu oleh norma atau aturan-aturan birokrasi, namun sebagai makluk sosial yang memiliki akal budi, kemampuan untuk berfikir, kemampuan berkehendak secara rasional, dan 
kemampuan berinovasi dan mampu untuk menciptakan perubahan menunuju pada siklus kehidupan sosial yang dirasa lebih baik.

Sejalan dengan perubahan era dalam masyarakat demokratis dan global, maka keberadaan manusia dituntut untuk dapat mengadaptasikan diri dan menyesuaikan serta mampu mengelola perubahan yang terus terjadi. Sumberdaya manusia menjadi titik kritis prubahan, karena dinilai sebagai modal dasar dan agen perubahan pembangunan itu sendiri. Sejalan dengan hal tersebut, maka ketersediaan sumberdaya manusia tidak hanya menyentuh aspek kuantitas atau jumlah, akan tetapi yang lebih penting adalah menyangkut aspek kapasitas yang dimiliki seperti kualitas, keahlian, kompetensi maupun profesionalisme.

Kepemilikan kapasitas dan kapabilitas sumberdaya manusia yang kompeten dan profesional akan mereaktualisasikan hakekat manusia sebagai manusia yang utuh dilihat dari sisi sosial, politik, budaya dan ekonomi. Manusia memiliki kemerdekaan untuk berkreasi, berpendapat dan mengambil keputusan akan nasib atas dirinya, dan di pihak lain akan mendorong menjadi agen pembaharuan atau perubahan yang menghantarkan perbaikan nasib bangsa dan negara menuju kesejahteraan dan kemakmuran bersama.

Konteks ketersediaan kapasitas sumber daya manusia yang kapabel dan unggul, juga sangat berhubungan dengan ketersediaan sumber daya aparatur sipil negara, baik di pusat dan di daerah. Eksistensi sumber daya Aparatur Sipil Negara, sebagai bagian dari penyelenggara negara dituntut pula untuk dapat mengikuti perkembangan dan tuntutan global saat ini, yakni kemampuan untuk dapat melayani tugas pokok dan fungsinya secara lebih profesional dan produktif. Saat ini, eksisting sumber daya Aparatur Sipil Negara, baik di pusat maupun di daerah tercatat sebanyak 4,7 juta pegawai, dimana 360.000 pegawai merupakan anggota Polri, dan 330.000 anggota TNI. Realitas tersebut menunjukkan bahwa jumlah sumber daya aparatur sipil negara yang demikian banyak dapat dimaknai sebagai modal Bangsa dan Negara yang harus selalu dijaga dengan baik, dikembangkan, dan dihargai.

Meskipun dilihat dari sisi kuantitas, jumlah PNS dapat dipandang sangatlah mencukupi untuk dapat melayani masyarakat secara lebih optimal dan merata, namun pada kenyataannya peran maupun tugas-pokok yang dijalankan belum dilaksanakan secara lebih optimal dan sungguhsungguh. Bahkan, banyak peneliti menyatakan telah terjadi prevalensi patologi birokrasi, yaitu suatu kecenderungan birokrasi yang hanya mengutamakan kepentingan sendiri (self-serving), mempertahankan status-quo dan resisten terhadap perubahan dan cenderung terpusat (centralized) sehingga menyebabkan kegagalan birokrasi pemerintah dalam menjalankan fungsi pelayanan dan pembangunan. Bagi Dennis A. Rondinelli (1981), kegagalan tersebut cenderung disebabkan oleh kuatnya komitmen budaya politik yang bernuansa sempit; kurangnya tenaga-tenaga kerja yang terlatih dan terampil dalam unit-unit lokal; kurangnya sumber dana untuk melaksanakan tugas dan tanggung jawab; adanya sikap keengganan untuk melakukan delegasi wewenang; dan kurangnya infrastruktur teknologi dan infrastruktur fisik dalam menunjang pelaksanaan tugas pelayanan publik. Sementara, menurut Malcolm Waters (1994), kegagalan birokrasi pemerintah lebih disebabkan karena aparat birokrasi tidak menyadari adanya perubahan dan pergeseran yang terjadi dalam budaya masyarakat dari budaya yang bersifat hirarkhis dan fatalis ke arah budaya-budaya yang bersifat individual dan egalitarian.

Fenomena kegagalan kinerja birokrasi tersebut, nampaknya juga diperkuat oleh hasil kajian PERC (Political and Economic Risk Consultancy), mengenai tingkatan efisiensi birokrasi di Indonesia pada tahun 2012. Skor penilaian ini bergerak antara 1-10, jika nilainya mendekati atau sama dengan 1 dapat dinilai sangat bagus (best), akan tetapi jika mendekati atau sama dengan 10 dapat dinilai sangat buruk (worsth). Jika dibandingkan dengan beberapa negara di ASIA, seperti Singapore, Hongkong, Thailand, China Taipe, Jepang, Korea Utara, Malaysia, China, Philipina, Vietnam dan India, maka posisi Indonesia berada di urutan ke tiga dari 
bawah. Skor Indonesia yang menunjukkan angka 8.37, lebih menggambarkan bahwa efisiensi birokrasi di Indonesia dapat dikatakan sangat rendah atau buruk.

Dalam rangka untuk memperbaiki kinerja birokrasi, maka pemerintah telah melakukan reformasi birokrasi. Meskipun reformasi birokrasi telah dijalankan mulai pertengahan tahun 2008 hingga saat ini, namun pelaksanaan reformasi tersebut terasa lamban dan bersifat incremental. Pada tahun 2008, reformasi birokrasi awalnya dimulai dari Kemetrian Keuangan dan berlanjut pada Kementrian Kehakiman dan Mahkamah Agung. Pada tahun berikutnya, reformasi diperluas ke kementrian dan Lembaga Pemerintah Non Kementrian (LPNK). Oleh karena reformasi bukan sekedar meletakkan dan berupaya memperbaiki kelembagaan, namun juga menyangkut aspek orang yang menjalankan lembaga tersebut, maka reformasi di bidang Aparatur Negara juga dilakukan.

Sejalan dengan kedudukan dan peran sumberdaya aparat yang demikian penting dan krusial untuk dapat memfasilitasi keberhasilan pembangunan dan layanan, maka pendekatan untuk menempatkan sumberdaya aparat perlu adanya reorientasi atau perubahan. Paradigma yang selama ini masih menempatkan pengelolaan sumberdaya aparat masih dalam perspektif lama sebagai manajemen kepegawaian perlu dirubah dan disesuaikan. Manajemen kepegawaian yang lebih menekankan hak dan kewajiban individual pegawai terasa sudah kurang sesuai dengan tuntutan zaman, sehingga perlu adanya reorientasi pada pespektif baru yang lebih menekankan pada strategi manajemen pengembangan sumber daya manusia (strategic human resource management). Perubahan orientasi ini diharapkan dapat menyediakan sumber daya aparatur sipil negara yang unggul dan profesional sejalan dengan tuntutan global.

Tuntutan perubahan paradigma dalam pengelolaan sumberdaya aparatur di lingkungan birokrasi akhirnya dapat terwujud dengan keluarnya UU Aparatur Sipil Negara (Indonesian Civil Service) sebagai pengganti dari keberadaan UU Pokok Kepegawaian yang sudah berusia 30 tahun. Dalam UU ASN terlihat adanya nuansa baru jika dibandingkan dengan yang lama, paling tidak ada 9 (sembilan) hal yang perlu dicatat, antara lain: (1) UU ASN memberikan koridor yang cukup baik dalam pengaturan pegawai pemerintah dengan perjanjian kerja (PPPK). (2) Secara filosofis UU ASN hanya mengenal eselonisasi hingga tingkat ke-2, yang disebut sebagai Jabatan Pimpinan Tinggi. Meskipun demikian, eselonisasi tetap dipertahankan dalam nama Jabatan Administrasi. (3) UU ini memberi pengakuan dan tanggung jawab kehormatan kepada pejabat tinggi (high rank officials) di birokrasi, yang disebut sebagai Jabatan Pimpinan Tinggi (JPT). JPT merupakan manifestasi dari gagasan senior executive service (SES) yang lazim di praktikkan di negara-negara yang telah menganut New Public Management (NPM). (4) UU ASN mengatur tentang kelembagaan dalam manajemen SDM aparatur. Hal ini dapat menghilangkan potensi tumpeng tindih kewenangan antara menteri di bidang pendayagunaan aparatur negara dan menteri di bidang dalam negeri. (5) UU ini menjadi dasar pembentukan KASN. Pembentukan KASN adalah manifestasi dari praktik governance di bidang pendayagunaan aparatur negara. Prinsip dasar dari governance adalah perluasan pelaksana pemerintahan dari pemerintah kepada aktor lain di negara, yaitu masyarakat sipil (civil society) dan sektor swasta. (6) UU ASN secara eksplisit menyebutkan bentuk pengembangan karier PNS dengan pemberian kesempatan praktik kerja di instansi lain termasuk perusahaan swasta paling lama selama satu tahun sebagai manefestasi dari gagasan reform leaders academy. (7) UU ASN membuka peluang diberhentikannya PNS atas alasan kinerja Hal ini tentu patut diapresiasi karena memberikan nuansa baru dalam birokrasi terutama dalam hal penilaian kinerja PNS. (8) UU ASN menjadikan pengisian JPT terbuka secara nasional. JPT sendiri terdiri dari tiga tingkatan, yaitu JPT utama (yang kini ekuivalen dengan Kepala LPNK), JPT madya (yang kini ekuivalen dengan eselon I), dan JPT pratama (yang kini ekuivalen dengan eselon II). (9) UU ASN memperkenalkan sistem kontrak pada JPT, yang berlaku per lima tahun. Hal ini mirip dengan yang dilakukan Australia, yaitu jabatan secretary di setiap kementerian hanya dapat diisi selama lima tahun dan selanjutnya harus dipilih 
kembali. Dengan demikian, diharapkan terjadi penyegaran dan tidak ada "pengkaplingan" jabatan oleh seseorang atau sekelompok orang .

Sejalan dengan fenomena perubahan paradigma dalam pengelolaan aparatur sipil negara dari paradigma kepegawaian kearah paradigma strategic human resource management, maka masalah yang dapat dirumuskan adalah 'bagaimanakah pengembangan kapasitas sumberdaya aparatur di daerah terutama kompetensi dan profesionalisme aparat dikontruksikan oleh para aparatur birokrasi lokal untuk menunjang perwujudan good local governance?

\section{Metode Penelitian}

Metode kajian yang digunakan dalam penelitian ini adalah kualitatif-deskriptif. Bagi Bogdan dan Taylor, penelitian kualitatif adalah proses penelitian yang menghasilkan data deskriptif berupa data tertulis/lisan dari subjek dan objek yang diamati/diteliti. Dalam konteks ini, peneliti memiliki peran penting untuk memproses hasil mulai dari analisis, perenungan dan intepretasi dari data-data yang sifatnya induktif.

Populasi dari penelitian ini adalah para aparatur pemerintah daerah di Kabupaten Bojonegoro, Provinsi Jawa Timur. Kemudian, sampel dipilih secara purposive untuk merepresentasikan keleluasan penelitian ini, terutama menyangkut sampel terhadap institusi dan orangnya. Institusi berbentuk Dinas diwakili oleh Dinas Kesehatan, Dinas PU, Dinas Pendidikan, Dinas Tenagakerja, Sosial dan Transmigrasi. Kemudian yang berbentuk Badan, yakni diwakili oleh Badan Perencanaan Daerah, Badan Kepegawaian Daerah. dan Badan Pemberdayaan Masyarakat. Sementara institusi yang berbentuk Kantor, diwakili oleh Kantor Ketahanan pangan dan Kantor Arsip dan Perpustakaan, dan yang mewakili Kecamatan ada 4 Kecamatan, yakni Kecamatan Bojonegoro, Kapas, Balen dan Dander. Jika dilihat dari banyaknya reponden, maka responden terpilih sebanyak 73 aparat.

Sifat pusposive ini menyangkut pemilihan aparatur yang bereselon tertentu dan mewakili aparatur yang berada di lingkungan Dinas, Badan, Kantor atau Kecamatan. Untuk tetap menjaga keterwakilan dalam penelitian ini, maka sampel akan dipilih terutama untuk lembaga-lembaga yang memiliki jumlah aparatur yang banyak dan memiliki tugas pokok yang sesuai dengan tujuan penelitian ini.

\section{Hasil Penelitian dan Pembahasan}

Tuntutan dan kebutuhan reformasi bidang kepemerintahan di kebanyakan negara berkembang dari sistem sentralisasi ke sistem desentralisasi telah menjadi fenomena global. Ada empat variabel pengungkit perubahan tersebut, yakni: 1) Politik: keunggulan demokrasi dan kekuatan publik serta keunggulan sistem pasar menimbulkan tekanan politik di berbagai negara di dunia untuk melakukan transformasi peran pemerintah untuk mengurangi peran dan fungsinya. 2) Sosial: beberapa negara di dunia telah mengalami perubahan sosial yang mendasar, yaitu melakukan rekonstruksi ulang terhadap tatanan hukum, ekonomi, sosial, dan politik ditandai pula oleh adanya perubahan mendasar dari masyarakat industri kepada masyarakat informasi. 3) Ekonomi: krisis ekonomi pada tahun 1990-an di berbagai negara di dunia melakukan reformasi di bidang perpajakan untuk menarik investor masuk, dan juga melakukan langkah-langkah privatisasi sebagai respon terhadap tekanan ekonomi. 4) Institusional: semua negara di dunia telah menjadi bagian dari sistem ekonomi dan politik global. Kondisi ini ditandai dengan semakin berkembangnya kelembagaan di luar negara seperti World Bank, IMF, WTO, ADB yang mengatur globalisasi dunia (Mariana 2009). 
Sistem desentralisasi banyak dinilai memberi nilai tambah (value added) bagi institusi lokal maupun komunitas sebagai pelanggan, seperti mempercepat pengambilan keputusan untuk problem solving, perbaikan layanan publik dan efisiensi. Meskipun secara teoritik sistem desentralisasi mampu memberi nilai tambah bagi institusi lokal, namun harus di dukung oleh kapasitas yang memadai. Kendala utama proses pembangunan di kebanyakan negara lebih disebabkan oleh keterbatasan kapasitas untuk menetapkan tujuan pembangunan, menetapkan prioritas di antara mereka dan merevisi rencana maupun program (Harris 2005, Hall 2008, Otto 2009).

Sejalan dengan hal tersebut, maka sebagian besar negara telah melakukan pemikiran kembali mengenai peran pemerintah yang lebih mengapresiasi hubungan di antara kualitas dan kinerja organisasi negara dan institusi yang menyangkut semua tingkatan kemajuan pembangunan kapasitas. Menurut Anneli Milen (ADB 2001, Boelger 2008, Bourgon 2010), kepentingan pembangunan kapasitas di dorong oleh dua hal, yakni: 1) kegagalan dalam kerjasama pembangunan untuk meng-hasilkan hasil pembangunan yang berkelanjutan dan 2) kebutuhan untuk memperkuat negara dan lembaga setelah pengalaman negatif dari kebijakan penyesuaian struktural, yang menekankan peran minimalis dan perampingan negara dan radikal di sektor publik.

Pembangunan kapasitas seringkali dimaknai sebagai sebuah strategi untuk meningkatkan efisiensi, efektivitas, dan responsivitas kinerja pemerintahan dengan memusatkan perhatian kepada tiga dimensi, yakni: (1) Pengembangan sumber daya manusia; (2) Penguatan organisasi; dan (3) Reformasi kelembagaan (Grindle 1997, UNDP 2009, Bappenas dan Depdagri 2000). Sementara Bank Dunia menegaskan bahwa pembangunan kapasitas akan terkait dengan lima dimensi, yakni: (1) pengembangan sumber daya manusia, khususnya training, rekruitmen, pemanfaatan dan pemberhentian tenaga kerja profesional, manajerial dan teknis; (2) organisasi, yaitu pengaturan struktur, proses, sumber daya, dan gaya manajemen; (3) jaringan kerja interaksi organisasi, yaitu koordinasi kegiatan-kegiatan organisasi, fungsi jaringan kerja, dan interaksi formal dan informal; (4) lingkungan organisasi, yaitu aturan dan perundang-undangan yang mengatur pelayanan publik, tanggung jawab dan kekuasaan antar lembaga, kebijakan yang menghambat tugas-tugas pembangunan, dan dukungan keuangan dan anggaran; dan (5) lingkungan kegiatan yang luas, yaitu mencakup faktor politik, ekonomi, dan kondisi-kondisi yang berpengaruh terhadap kinerja.

Terkait dengan pengembangan kapasitas sumberdaya manusia, secara spesifik ditegaskan oleh Berry (1990, Smith 2010, Maconick 2010), bahwa pengembangan kapasitas akan terkait dengan seberapa jauh staff mampu menunjukkan kontribusi yang nyata terhadap pengembangan personal, organisasi dan masyarakat. Salah satu upaya pengembangan persoalan dengan dilakukan program pelatihan. Menurut William B. Werther (Swanson \& Holton 2001, Gary Desler 2003), pengembangan pelatihan dapat menyangkut (1) need assessment; (2) training and development objective; (3) program content;(4) learning principles; (5) actual program; (6) skill knowledge ability of works; dan (7) evaluation. Sementara menurut Simamora (1997), dalam program pengembangan pelatihan ada delapan langkah, yaitu: (1) tahap penilaian kebutuhan dan sumber daya untuk pelatihan; (2) mengidentifikasi sasaran-sasaran pelatihan; (3) menyusun kriteria; (4) pretes terhadap pemagangan; (5) memilih teknik pelatihan dan prinsip-prinsip proses belajar; (b) melaksanakan pelatihan; (7) memantau pelatihan; dan (8) membandingkan hasil-hasil pelatihan terhadap kriteria-kriteria yang digunakan.

Mendasarkan konstruksi teoritik tersebut terlihat bahwa pembangunan kapasitas memiliki variasi yang sangat beragam dan dipihak lain pembangunan kapasitas sangat dibutuhkan dalam rangka meningkatkan kapasitas sistem, institusi dan orang untuk dapat menjakankan sistem desentralisasi secara optimal dan penciptaan terhadap „good local governance'. Seiring dengan hal tersebut, nampaknya banyak konstruksi empiris juga 
memperkuat relasi teoritis melalui beberapa hasil kajian, yakni: Pertama, menurut hasil penelitian yang dilakukan oleh GTZ Support for Decentralization Measurement di Propinsi Kalimantan Timur (2002), kapasitas institusi local dipandang masih lemah. Persoalan yang menyangkut kelembagaan, yakni: 1) Pembentukan kelembagaan/ organisasi perangkat daerah belum menggunakan indikator yang baik, 2) masih terjadi tumpang tindih dalam tupoksi antar unit organisasi, 3) Koordinasi, komunikasi dan informasi belum terjalin dengan baik (internal/eksternal maupun vertical/ horizontal). Sedangkan permasalahan pada tingkat aparat adalah: 1) kualitas pegawai masih kurang, 2) Kualitas pegawai masih terbatas, 3) Persyaratan administrative pegawai masih terbatas untuk menduduki jabatan structural tertentu, 4) Motivasi kerja pegawai masih rendah.

Kedua, menurut hasil kajian dari Center for Local Government Innovation (CLGI) dan Urban and Regional Development Institute (URDI) (2004), telah melakukan mapping upaya peningkatan kapasitas Pemerintah Daerah, yakni ada 23 lembaga donor asing yang bekerja di 9 sektor peningkatan kapasitas, baik di Pusat maupun di Propinsi yang mencakup 381 proyek selama tahun 2000 hingga 2003, dan saat ini ada 57 program dan/atau proyek yang sedang berjalan yang berkaitan erat dengan upaya peningkatan kapasitas di Indonesia.

Ketiga, Menurut hasil kajian Jeremy Hall (2008), ditegaskan bahwa pembangu-nan kapasitas memiliki hubungan yang signifikan dengan perbaikan pemerintah lokal. Hal senada juga ditunjukkan dari hasil kajiannya Carol J De Vitta (2001), di mana KCPP (Knight Community Partners Program) yang telah melakukan pembangunan kapasitas dengan tujuan mengembangkan kualitas kehidupan di 26 komunitas di Amerika Serikat dengan cara mengembangkan kapasitas organisasi non-profit menjadi sebuah elemen kritis dalam pencapaian kualitas kehidupan masyarakat itu sendiri.

Keempat, Menurut hasil studi pembangunan kapasitas yang didanai oleh Aus-AID di Papuan New Guinea dibawah program PPII (Provincial Performance Improvement Initiative) dan CBSC (Capacity Building Service Centre), telah dilakukan upaya untuk membangun diagnosis secara intensif pada cara pelayanan di negara tersebut, namun kunci hambatannya terletak pada aspek institusional. Desain pembangunan kapasitas secara sistematis berupaya mengembangkan kapasitas organisasi propinsi dan administrasi pemerintahan lokal yang berhubungan dengan pemberian layanan. Kedua program tersebut telah mampu mengembangkan sasaran kapasitas yang dapat didefinisikan lebih eksplisit dan holistik.

Kelima, berdasarkan hasil studi tahun ke 1 (satu) tentang konstruksi capacity human development model dalam mewujudkan 'good local governance', (2013), terlihat bahwa pengembangan kapasitas dimaknai sangat dinamis bagi aparat eselon III. Hasil kajian tahap pertama menegaskan beberapa hal, yakni: a). Pengembangan kapasitas aparat di Kabupaten Bojonegoro dikonstruksikan sebagai sebuah pengetahuan atau pemahaman yang bersifat multiperspektif, pluralistik dan inklusif dengan cara subjekif yang dibentuk melalui beragam keyakinan ide. b). Pemaknaan Pengembangan kapasitas aparat dikonstruksi-kan sebagai sebuah proses perubahan secara menyeluruh yang berelasi dengan aturan internal dan tupoksi, kualitas SDM aparat lokal (skill, profesionalisme dan kompetensi), dan hasil pembangunan. c). Konstruksi yang mampu dibangun oleh aparat terhadap prinsip tata kepemerintahan lokal yang baik (good local governance) untuk Kabupaten Bojonegoro berelasi dengan a) Proses pembangunan, b) Pemberdayaan, c) Penegakan Hukum dan Aturan, d) Layanan Publik, e) Kerjasama dan f) Profesionalisme Aparat.

Seiring dengan diskursus teoritik dan empiris di atas, terutama melihat hasil kajian tahun pertama, terlihat bahwa capacity human development telah menjadi 'global paradigm' dan menjelma sebagai realitas sosial, karena kehadirannya bukanlah bersifat statis, akan tetapi terus bergerak dan berubah untuk dikonstruksikan kembali sebagai suatu dinamika yang bersifat organis. Untuk mendapatkan pengetahuan dan pemahaman yang origional mengenai capacity 
human development dalam konteks good local governance yang lebih luas dan menyeluruh meliputi semua aparatur terutama eselon III, IV dan Staf di lingkungan birokrasi lokal menjadi sangat penting untuk menguatkan sebuah pemodelan atas pengembangan kapasitas aparatur dalam mewujudkan good local governance.

\section{Konstruksi profesionalisme aparat}

Sejalan dengan berjalannya era reformasi, maka arah pengembangan kebijakan kepegawaian telah berubah seiring dengan perubahan tuntutan lingkungan. Keberadaan Undang-Undang Nomor 8 Tahun 1974 tentang Pokok Pokok Kepegawaian akhirnya telah diperbaiki melalui Undang-Undang Nomor 43 Tahun 1999, namun pada perjalanan kemudian, arah kebijakan kepegawaian Negara telah berubah dengan keluarnya UU Aparatur Sipil Negara.

Melalui UU No 8 tahun 1974, negara menetapkan dan menerapkan sistem kepegawaian berbasis karir yang menekankan pada hak, kewajiban, tugas, dan tata cara pengelolaan pegawai negeri secara tersentralisir. Sejalan dengan reformasi kepemerintahan yang meletakkan dasar pada desentralisasi, maka pengelolaan kepegawian dilakukan secara terdesentralisir melalui perubahan kebijakan dengan dikeluarkannya UU No 43 tahun 1999. Meskipun kebijakan perundangan ini dipandang lebih baik dan banyak memberi kewenangan yang besar bagi daerah terutama Badan Kepegawaian Daerah (BKD), akan tetapi hasilnya dinilai kurang optimal. Oleh karena keberadaan dan eksistensi sumberdaya manusia selaku aparat merupakan modal dasar bagi perwujudan pembangunan dan pelayanan yang prima di daerah, dan dipihak lain semakin tingginya tantangan yang harus dihadapi oleh aparat dalam mengelola lingkungan yang terus berubah di erah globalisasi dan liberalisasi, maka tidak ada pilihan lain, pihak pemerintah untuk melakukan perbaikan kebijakan kepegawaian yang lebih mengarah pada tuntutan dan kebutuhan zamannya.

Keluarnya UU ASN yang diilhami dengan pemikiran pada pengelolaan kepegawaian di negaranegara maju diharapkan mampu mendukung pembangunan tata kepemerintahan demokratis dan desentralistis. Di samping itu, melalui UU ASN (Indonesian Civil Service) diharapkan akan mampu meningkatkan kapasitas bagi 4.7 juta PNS dan sekitar 1 juta pegawai tidak tetap yang menyebar di 33 provinsi dan 497 kabupaten dan kota.

Melalui perubahan kebijakan kepegawaian tersebut, diharapkan pula akan tersedia putra-putri terbaik bangsa sebagai Pegawai Negeri Sipil. Hal ini merupakan landasan dasar pembentukan Pegawai Negeri Sipil yang profesional, pembentukan birokrasi Pemerintah yang modern dan berkelas dunia serta dapat memulihkan kepercayaan masyarakat dan generasi muda bahwa untuk menjadi Pegawai Negeri Sipil harus bertumpu pada kemampuan diri sendiri.

Keberadaan UU ASN telah mengkonstruksikan dan mengarahkan pembentukan dan perwujudan sumberdaya aparatur yang berkompeten dan Profesional. Konteks tersebut, nampaknya juga diyakini dan dipercaya oleh sebagian besar responden di Kabupaten Bojonegoro.

Mendasarkan hasil temuan kajian di lapangan, menurut $60.27 \%$ responden menyatakan 'sangat setuju', bahwa 'Profesionalisme Aparatur di daerah sangat dibutuhkan untuk dapat meningkatkan trust building kelembagaan pemerintah daerah', sementara menurut $39.73 \%$ responden lainnya menyatakan 'setuju'. Konteks tersebut menunjukkan bahwa ada rasa optimisme dan rasa keyakinan yang tinggi dari para aparat, yang menegaskan bahwa eksistensi profesionalisme aparat bisa memberi dampak bagi peningkatan trust-building kelembagaan Pemerintahan Daerah.

Hal yang sama juga terjadi pada keyakinan dan kepercayaan mereka terhadap kemampuan untuk mewujudkan visi dan misi kelembagaan. Menurut 61,64\% responden, menyatakan 'sangat setuju' bahwa 'Profesionalisme Aparatur di daerah sangat dibutuhkan untuk dapat 
mendorong perwujudan visi dan misi Kabupaten dan SKPD', sementara $38.36 \%$ responden lainnya, menyatakan 'setuju'. Konstruksi tersebut mempertegas bahwa ada keyakinan dan kepercayaan yang tinggi dari para aparat yang mempertegas adanya relasi antara profesionalisme yang dimiliki aparat di Kabupaten dengan akses pencapaian visi dan misi Kabupaten.

Kontestasi tersebut, nampaknya sama juga dengan keyakinan dan kepercayaan responden mengenai relasi antara profesionalisme dengan akses terhadap kelancaran tugas. Menurut 57.53\% responden, menyatakan 'sangat setuju' bahwa 'Profesional Aparatur di daerah sangat dibutuhkan untuk dapat menunjang kelancaran tugas pokok dan fungsi (tupoksi) serta pencapaian kinerja individu'. Sedangkan menurut $41.10 \%$ responden lainnya, menyatakan 'setuju' dan hanya $1,37 \%$ yang menyatakan 'tidak setuju'.

Keyakinan dan kepercayaan terhadap eksistensi atau perwujudan profesionalisme yang disebabkan oleh sistem pendapatan, juga diyakini sepenuhnya oleh para aparat. Menurut 50.68\% responden, menyatakan 'sangat setuju' bahwa 'Profesionalisme Aparatur di daerah harus diikuti dengan sistem pendapatan (gaji dan tunjangan) yang besar dan layak'. Sementara $26.03 \%$ responden lainnya menyatakan 'setuju', dan $15.1 \%$ responden menyatakan 'kurang setuju', sementara $8.22 \%$ responden menyatakan 'tidak setuju'. Meskipun ada keragaman keyakinan dan kepercayaan pada aparat terkait dengan pernyataan tersebut, namun dapat terlihat garis merahnya, dimana sebagian besar tetap meyakini bahwa ada relasi antara perwujudan profesionalisme itu sendiri dengan sistem pendapatan yang akan diterima secara layak.

\section{Konstruksi dukungan unsur pimpinan}

Sejalan dengan berlakunya UU No 32 tahun 2004, maka kewenangan dan kekuasaan Pemerintah Daerah menjadi semakin jelas dan kuat terutama untuk dapat mengurus rumah tangganya sendiri. Ada dua hal yang mendukung kekuasaan dan kewenangan Pemerintah Daerah menjadi semakin tinggi, yakni secara struktural organisasasi Pemerintah Daerah tidak dibawah Pemerintah Provinsi, dan kedudukan Bupati dan Wakil Bupati selaku unsur pimpinan di daerah lebih dikarenkan dipilih langsung oleh masyarakat melalui Pilkada.

Berkenaan dengan hal tersebut, maka kedudukan dan eksistensi unsur pimpinan daerah, yakni Bupati dan Wakil Bupati menjadi sangat sentral dan kuat. Jika demikian halnya, maka keberhasilan penyelenggaraan pemerintahan, pembangunan dan penyediaan layanan kepada masyarakat secara optimal dan prima, sangat ditentukan oleh kapasitas manajerial pimpinan kepala daerah. Kapasitas manajerial dapat dilihat dari role model pemimpin ataupun kemampuan untuk memotivasi, menggerakkan dan mengarahkan sumberdaya aparat di bawahnya untuk dapat mewujudkan visi dan misi yang telah ditetapkan. Di samping itu, kapasitas kepemimpinan dalam unit organisasi juga memiliki peran yang penting pula untuk memotivasi, menggerakkan serta mengarahkan kerja aparat dibawahnya untuk bisa mewujudkan visi dan misi SKPD.

Meskipun secara normatif unsur pimpinan Daerah dan SKPD menjadi faktor yang dominan dalam mengarahkan setiap gerak dan langkah para pegawai sebagai bawahannya, akan tetapi persepsi para aparat menjadi sangat bervariasi.

Mendasarkan hasil kajian di lapangan, menurut 23.29\% responden menyatakan 'sangat setuju', bahwa 'telah ada beberapa kebijakan daerah, baik berupa Perda, Peraturan atau Keputusan Bupati dan Kepala SKPD dalam upaya untuk mewujudkan profesionalisme Aparat Sipil Daerah'. Sementara $71.23 \%$ responden menyatakan 'setuju', dan $5.5 \%$ responden menyatakan 'kurang setuju'. Hal tersebut menegaskan bahwa fungsi dan pemeranan pemerintah daerah untuk dapat menghasilkan produk kebijakan, baik berupa perda dan keputusan/peraturan kepala daerah di Kabupaten Bojonegoro diyakini dan dipercaya telah dilakukan secara optimal. 
Paling tidak, dengan keluarnya beragam perubahan Perda atau Keputusan/ Peraturan Bupati yang menyangkut Tugas Pokok dan Fungsi masing-masing SKPD ditujukan untuk mengotimalkan peran yang dapat dijalankan oleh para aparat itu sendiri. Di pihak lain, dengan keluarnya Peraturan Bupati No. 28 tahun 2011 tentang Tambahan Penghasilan Pegawai Negeri Sipil Berdasarkan Beban Kerja dan Prestasi Kerja juga ditujukan untuk merangsang dan mendorong perbaikan kinerja individu secara lebih baik.

Kemudian terkait peran pimpinan SKPD dalam memotivasi anak buahnya, nampaknya diyakini dan dipercaya oleh para aparatur bawahannya telah dilakukan secara optimal. Menurut $41.10 \%$ responden menyatakan 'sangat setuju' bahwa 'Pimpinan SKPD selalu memotivasi, mendorong serta mengarahkan agar para pegawainya dapat bersikap dan memiliki nilai-nilai profesionalisme dalam menjalankan tugas keseharian'. Sementara menurut 56.16\% responden lainnya menyatakan 'setuju', dan $2.7 \%$ responden sisanya menyatakan 'kurang setuju'. Konteks ini menegaskan bahwa pemeranan kepemimpinan yang dijalankan oleh masing-masing ketua SKPD terutama untuk memotivasi, mendorong dan mengarahkan para aparat di bawahnya untuk dapat bekerja secara profesional, telah dijalankan dengan baik.

Realitas tersebut di atas, nampaknya sejalan dengan pernyataan aparat terkait dengan pemeranan unsur pimpinan daerah dalam memotivasi aparat/karyawan Menurut $41.10 \%$ responden menyatakan 'sangat setuju', bahwa 'Unsur Pimpinan Pemerintah Daerah (Bupati dan Wakil Bupati) selalu memotivasi, mendorong serta mengarahkan agar para pegawainya dapat bersikap dan memiliki nilai-nilai profesionalisme dalam menjalankan tugas keseharian'. Kemudian menurut $57.53 \%$ responden menyatakan 'setuju', dan $1.4 \%$ responden sisanya menyatakan 'kurang setuju'. Konteks ini menegaskan bahwa pemeranan unsur pimpinan, terutama Bupati dan Waki Bupati memiliki peran yang sangat strategis dan optimal untuk mendorong dan memotivasi kinerja para karyawan di lingkungan Pemerintah Daerah Kabupaten Bojonegoro.

Keyakinan dan kepercayaan aparat yang menegaskan bahwa unsur pimpinan dan kepala SKPD telah bekerja sesuai fungsinya untuk mendorong dan memotivasi serta merangsang kinerja karyawan, nampaknya teruji dalam tanggapan konfermasi lainnya. Menurut $12.33 \%$ responden menyatakan 'sangat setuju', bahwa 'Untuk mewujudkan keprofesionalan pegawai, tidak ada arahan atau dukungan yang jelas dan tegas dari unsur pimpinan daerah ataupun pimpinan SKPD'. Sementara $12.33 \%$ responden menyatakan 'setuju', dan 35,6\% responden menyatakan 'kurang setuju', kemudian sebagian besar, yakni 39.73\% responden menyatakan 'tidak setuju'. Kepercayaan dan keyakinan aparat melalui tanggapan konfirmasi ini telah menegaskan kembali bahwasannya kehadiran dan pemeranan unsur pimpinan dan kepala SKPD benar-benar telah bekerja secara optimal dalam mendorong, memotivasi serta mengarahkan kinerja karyawan secara lebih baik.

\section{Konstruksi terhadap kesejahteraan, kejujuran dan etos kerja aparat}

Fenomena meluasnya Korupsi, Kolusi, Nepotisme $(\mathrm{KKN})$ yang menyentuh di kalangan dan lingkaran birokrasi di daerah dianggap semakin intens dan transparan. ketika desentralisasi diterapkan. Di satu sisi, kekuasaan dan kewenangan yang diberikan dan dikelola di daerah semakin besar dan di pihak lain kesejahteraan para pegawai di daerah dinilai masih kurang memadai, sehingga potensi terjadinya korupsi menjadi semakin tinggi.

Sejalan dengan realitas tersebut, maka upaya terencana yang dilakukan oleh pemerintah kabupaten untuk menambah tunjangan bagi para pegawai yang saat ini berlangsung harus dipahami sebagai bagian upaya untuk mengurangi terjadinya kecurangan atau korupsi yang dilakukan oleh aparat di daerah. Di samping itu, keluarnya UU ASN diharapkan pula menjadi arah dan pedoman bagi semua PNS untuk bisa bekerja secara profesional sejalan dengan sistem pemberlakukan kesejahteraan yang lebih baik di kalangan PNS. 
Di dalam UU ASN ditegaskan bahwa kesejahteraan pegawai dan kesejahteraan pensiun pegawai merupakan bagian penting dari manajemen kepegawaian Aparatur Sipil Negara. Melalui penerapan sistem penggajian skala tunggal yang berbasis kinerja, dan ditambah dengan tunjangan kinerja dan atau tunjangan kemahalan regional akan meningkatkan kesejahteraan pegawai itu sendiri.

Melalui kesejahteraan pegawai yang tinggi, maka profesionalisme pegawai dapat diwujudkan. UU ini juga menegaskan adanya perubahan yang mendasar dalam sistem pensiunan pegawai, dari pay as you go menjadi sistem fully funded. Kebijakan ini hanya akan diberlakukan bagi semua pegawai Aparatur Sipil Negara yang diangkat mulai 1 Januari 2012.

Upaya peningkatan kesejahteraan aparat di lingkungan pemerintah daerah Kabupaten Bojonegoro sebenarnya telah dilaksanakan semenjak tahun 2011 yang dikuatkan melalui Peraturan Bupati No. 28 tahun 2011 tentang Tambahan Penghasilan Pegawai Negeri Sipil Berdasarkan Beban Kerja dan Prestasi Kerja. Setelah kebijakan tersebut dilaksanakan dan dievaluasi dan menegaskan bahwasannya semua SKPD di lingkungan Pemerintahan Kabupaten Bojonegoro menunjukkan adanya peningkatan kinerja pegawai dengan adanya tambahan penghasilan yang diberikan sebagai stimulus dalam pelaksanaan tugas dan tanggungjawab sesuai dengan tupoksinya, maka telah dilakukan penyesuaian dan atau penambahan nilai nominal atas Tambahan Penghasilan melalui Peraturan Bupati No 47 tahun 2012.

Tabel 1.

Jenis eselon dan besarnya tunjangan per bulan

\begin{tabular}{|c|c|c|c|}
\hline \multirow[b]{2}{*}{ No } & \multirow[b]{2}{*}{ ESELON/JABATAN } & \multicolumn{2}{|c|}{ Besarnya Tunjangan/ bulan } \\
\hline & & 2011 & 2012 \\
\hline 1 & Eselon II a & $\begin{array}{r}\mathrm{Rp} . \\
750.000\end{array}$ & Rp. 900.000 \\
\hline 2 & Eselon II b & $\begin{array}{r}\text { Rp. } \\
450.000\end{array}$ & Rp. 900.000 \\
\hline 3 & Eselon IIIa & $\begin{array}{r}\text { Rp. } \\
350.000\end{array}$ & Rp. 600.000 \\
\hline & $\begin{array}{l}\text { a. Kepala Bagian Sekda dan } \\
\text { SKPD }\end{array}$ & $\begin{array}{r}\text { Rp. } \\
225.000\end{array}$ & Rp. 600.000 \\
\hline & 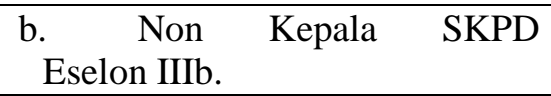 & $\begin{array}{r}\text { Rp. } \\
200.000\end{array}$ & Rp. 600.000 \\
\hline 4 & Eselon IV a & $\begin{array}{r}\text { Rp. } \\
175.000\end{array}$ & Rp. 500.000 \\
\hline 5 & Eselon IV b & $\begin{array}{r}\text { Rp. } \\
150.000\end{array}$ & Rp. 500.000 \\
\hline 6 & Eselon V a & $\begin{array}{r}\text { Rp. } \\
125.000\end{array}$ & Rp. 375.000 \\
\hline 7 & Staf & $\begin{array}{r}\text { Rp. } \\
100.000\end{array}$ & Rp. 350.000 \\
\hline
\end{tabular}

Secara lebih khusus, Pemerintah Kabupaten Bojonegoro juga telah mengeluarkan Peraturan Bupati No 12 tahun 2013 tentang Sistem Remunerasi pada Dinas Kesehatan. Mendasarkan isi pasal 4, terlihat bahwa tujuan sistem remunerasi pada Dinas Kesehatan, antara lain: a). Meningkatkan mutu pelayanan kesehatan di Puskesmas dan Labkesda untuk membangun citra pelayanan publik Pemerintah Kabupaten Bojonegoro kepada Masyarakat, b). meningkatkan kinerja keuangan dan kinerja pelayanan kesehatan di Puskesmas dan UPTD Labkesda, c). meningkatkan kesejahteraan seluruh pegawai di Puskesmas, Labkesda dan Dinas Kesehatan 
Kabupaten, d). meningkatkan motivasi dan disiplin kerja dalam mewujudkan pelayanan kesehatan yang bermutu dan memuaskan sesuai tanggung jawab profesi dan tugas pokok masing-masing, e). terwujudnya akuntabilitas publik dalam pengelolaan keuangan daerah yang bersumber dari pendapatan retribusi pelayanan kesehatan, f). meningkatkan indeks kepuasan masyarakat terhadap mutu dan akses pelayanan kesehatan di Puskesmas atau di Labkesda, g). Berjalannya fungsi pembinaan dan pengendalian manajemen pengelolaan Puskesmas dan Labkesda secara efektif.

Dalam sistem remunerasi pada Dinas Kesehatan tersebut telah terbagi penerima remunerasi, yakni penerima remunerasi langsung dan penerima remunerasi tidak langsung. Di samping itu, alokasi remunerasi juga telah ditetapkan, di mana 5\% dialokasikan pada penerima remunerasi tidak langsung dan $95 \%$ dipergunakan untuk penerima remunerasi langsung. Sementara cara untuk menghitung alokasi remunerasi didasarkan pada indeksing yang masing-masing memiliki bobot atau grade, antara lain: a). Indeks Kemampuan (Competency Index), b). Indeks Risiko (Risk Index), c). Indeks Jabatan (Position Index) dan d). Indeks Kinerja (Performance Index).

Meskipun pemerintah Daerah Kabupaten Bojonegoro telah mampu memberi tunjangan penghasilan bagi semua PNS serta perubahan nilai nominal Tunjangan Penghasilan di tahun berikutnya, namun upaya penciptaan terhadap profesionalisme aparat bukan hanya ditentukan oleh keberadaan tunjangan penghasilan semata, namun masih ditunjang oleh faktor lainnya, seperti kedisiplinan, etos kerja, ketepatan penempatan jabatan berbasis pendidikan dan kompetensi maupun kejujuran pegawai itu sendiri.

Mendasarkan hasil temuan di lapangan, menurut 23.29\% responden menyatakan 'sangat setuju', bahwa "Pemerintah daerah belum mampu memberi tambahan tunjangan yang layak sehingga para pegawai masih enggan bekerja secara berdaya guna dan berhasil guna". Sementara $15.62 \%$ responden menyatakan 'setuju', kemudian $34.2 \%$ responden menyatakan 'kurang setuju', dan $6.85 \%$ responden lainnya menyatakan 'tidak setuju'. Meskipun keyakinan dan kepercayaan para aparat ada yang membenarkan pernyataan tersebut, namun kecenderungan jawaban responden justru memberi konfirmasi kebalikannya, yang mana tambahan tunjangan yang diberikan dinilai mampu memberi dorongan dan spirit bagi aparat untuk dapat bekerja secara berdaya guna dan berhasil guna.

Realitas yang sama terjadi pada pernyataan responden terkait dengan dampak tunjangan terhadap etos dan disiplin kerja karyawan. Menurut $13.89 \%$ responden menyatakan 'sangat setuju', bahwa "Meskipun pemerintah daerah telah menerapkan dan memberi tambahan tunjangan pegawai, namun etos kerja dan disiplin kerja pegawai masih sangat rendah". Sementara $33.33 \%$ responden lainnya menyatakan 'setuju', kemudian $34.7 \%$ menyatakan 'kurang setuju', dan $18.06 \%$ responden sisanya menyatakan 'tidak setuju'. Pernyataan tersebut menegaskan, meskipun sebagian para aparat membenarkan pernyataan tersebut, akan tetapi kecenderungan jawaban responden justru memberi konfirmasi kebalikannya, yang mana tambahan tunjangan yang diberikan dinilai tidak berdampak pada merosotnya etos kerja maupun rendahnya disiplin pegawai di Kabupaten Bojonegoro.

Konfirmasi jawaban responden juga terlihat pada pernyataan terkait dengan penempatan pegawai. Menurut $19.18 \%$ responden menyatakan 'sangat setuju' bahwa 'Penempatan dan pengangkatan pegawai dalam jabatan tidak semuanya mendasarkan latar belakang pendidikan, pengalaman dan kompetensi (the right man in the right place)'. Sementara menurut $31.51 \%$ responden menyatakan 'setuju', dan $43.8 \%$ menyatakan 'kurang setuju', sementara yang lainnya, yakni 5.48\% menyatakan 'tidak setuju'. Meskipun disadari masih ada pegawai yang meyakini dan mempercayai masih adanya penempatan dan pengangkatan pegawai yang tidak didasarkan atas latar belakang pendidikan, pengalaman dan kompensi, namun justru sebagian besar menyatakan sebaliknya. Konteks ini menjelaskan bahwa masih ada ruang di mana 
sebagian besar aparat meyakini dan mempercayai bahwasannya the right man in right place bisa berjalan sebagaimana mestinya.

Pernyataan di atas, pada kenyataannya juga sejalan dengan pernyataan responden terhadap penempatan pegawai atas dasar like and dislike. Menurut $16.44 \%$ responden 'sangat setuju', bahwa 'Penempatan dan pengangkatan pegawai dalam jabatan masih sering mendasarkan like and dislike, "koncoisme" atau faktor-faktor politis tertentu'. Sementara menurut $20.55 \%$ responden menyatakan 'setuju', dan $28.8 \%$ menyatakan 'kurang setuju', kemudian $34.25 \%$ responden lainnya menyatakan 'tidak setuju'. Meskipun disadari masih ada juga pegawai yang meyakini dan mempercayai masih adanya penempatan dan pengangkatan pegawai didasarkan like and dislike, namun justru sebagian besar menyatakan sebaliknya. Konteks ini menjelaskan bahwa sebagian besar aparat meyakini dan mempercayai bahwa penempatan dan pengangkatan pegawai dalam jabatan tidak didasarkan atas like and dislike, 'koncoisme' atau faktor-faktor politis tertentu.

Kemudian terkait dengan pernyataan mengenai relasi antara pendidikan dan pelatihan yang pernah diterima dengan perwujudan profesionalisme aparat, nampaknya memiliki keragaman pandangan. Menurut 9.59\% responden, menyatakan 'sangat setuju', bahwa 'Pendidikan dan pelatihan yang telah diselenggarakan oleh pihak pemerintah daerah, baik melalui diklat fungsional dan tekniks (bintek) belum mampu menunjang keprofesionalan sumber daya Aparatur Sipil Negara'. Sementara menurut 32.88\% responden menyatakan 'setuju', dan 50.7\% menyatakan 'kurang setuju', dan $6.85 \%$ responden menyatakan 'tidak setuju'. Jawaban responden yang konfirmatif tersebut lebih menegaskan bahwa masih ada kepercayaan dan keyakinan aparat terhadap dampak pelatihan dan pendidikan yang diterima atau dijalankan selama ini memiliki akses untuk mewujudkan profesionalitas pegawai di Kabupaten Bojonegoro.

Konstruksi tersebut di atas, nampaknya sedikit berbeda dengan pernyataan aparat terhadap kehadiran Teknologi informasi untuk menjaring pegawai yang kompeten secara online. Menurut $46.58 \%$ responden menyatakan 'sangat setuju' bahwa 'Transparansi sistem penerimaan pegawai yang memanfaatkan teknologi informasi secara online dapat menyaring dan memperoleh calon Aparatur Sipil Negara yang kompeten dan profesional'. Sementara menurut $46.58 \%$ responden menyatakan 'setuju', dan 6.8\% menyatakan 'kurang setuju'. Konteks ini lebih menegaskan bahwa penerimaan dan penyaringan pegawai secara online, diyakini oleh sebagian besar akan bisa mendapatkan calon-calon pegawai yang kompeten dan profesional, dibandingkan dengan metode penerimaan dan penyaringan secara tradisional (face to face).

Keyakinan dan kepercayaan para responden, nampaknya juga tergambar pada pernyataan pada aspek kejujuran, sopan santun sebagai bagian dari instrumen atau indikator keprofesionalan pegawai. Menurut 49,32\% responden, menyatakan 'sangat setuju' bahwa 'Kejujuran, sopan santun dan etika kerja seseorang pegawai juga merupakan bagian penting dari keprofesionalan seseorang pegawai di daerah'. Kemudian, menurut 50.68\% responden lainnya menyatakan 'setuju'. Konstruksi pandangan tersebut jelas mempertegas bahwa profesionalisme pegawai tidak sekedar diukur dari aspek pendidikan, keahlian dan pengalaman yang dimiliki, namun juga menyangkut aspek sifat-sifat intrinsik individu, yakni kejujuran, sopan santun dan etika kerja seseorang.

Pandangan tersebut di atas, nampaknya sedikit berbeda dengan pernyataan pegawai atas relasi antara pendidikan dan kejujuran. Menurut $20.55 \%$ responden menyatakan 'sangat setuju', bahwa 'masih terdapat aparat yang memiliki latar belakang pendidikan tinggi dan pengalaman serta ketrampilan yang bagus, namun kurang memiliki kejujuran dan etos kerja yang baik'. Sementara menurut $57.53 \%$ responden menyatakan 'setuju', dan $16.4 \%$ responden lainnya menyatakan 'kurang setuju', sementara $5.48 \%$ responden sisanya menyatakan 'tidak setuju'. Kepercayaan dan keyakinan para responden nampak cukup dominan untuk menegaskan bahwa 
meskipun banyak pegawai/aparat memiliki latar belakang pendidikan tinggi, pengalaman dan ketrampilan, namun kurang memiliki nilai-nilai kejujuran dan etos kerja yang baik.

\section{Simpulan}

Memasuki perjalanan kehidupan pada era globalisasi di abad 21 ini, semua negara dan pemerintahan telah menyibukkan diri untuk merencanakan pengembangan kualitas dan kapasitas sumberdaya masyarakat. Tantangan dan peluang dalam kehidupan sosial masyarakat di era globalisasi, menuntut kualitas sumberdaya yang lebih kompetitif, profesional dan terampil.

Sejalan dengan berlakunya sistem pemerintahan yang terdesentralisir, maka eksistensi dan pemeranan sumberdaya aparat lokal menjadi kian penting dan utama, khususnya untuk bisa menyelenggarakan fungsi-fungsi pelayanan kepada masyarakat secara lebih optimal, murah dan memuaskan. Sehubungan dengan hal tersebut, maka tidaklah salah jika kemudian keberhasilan penyelenggaraan desentralisasi terutama terkait dengan penyelenggaraan fungsi-fungsi pelayanan sangat ditopang oleh eksistensi profesionalisme para aparatur maupun kapasitas kepemimpinan di daerah. Mendasarkan hasil kajian pada penelitian tahun ke 2 ini, dapat disimpulkan beberapa hasil temuan, yakni: Konstruksi aparat terhadap pernyataan visi Bojonegoro sebagai Lumbung Pangan dan Energi Negeri yang Produktif, Berdaya Saing, Adil, Sejahtera, Bahagia, dan Berkelanjutan diyakini dan dipercaya akan dapat direalisasikan pada akhir tahun 2018.

Konstruksi para aparat meyakini dan mempercayai bahwa capaian misi dapat diwujudkan secara lebih optimal, terutama pada misi perwujudan kesejahteraan, sumberdaya, infrastruktur dan kelestarian lingkungan, sementara kepercayaan yang kurang optimal terlihat pada perwujudan misi 'perekonomian, rujukan kesehatan dan tatakelola pemerintahan yang profesional'. Konstruksi para aparat meyakini dan mempercayai bahwa realitas desentralisasi akan memberi dampak terhadap berkembangnya KKN di daerah, namun tidak diyakini dan dipercayai akan meningkatkan eskalasi konflik maupun kesenjangan ekonomi. Konstruksi para aparat meyakini dan mempercayai bahwa kompetensi aparat akan mampu membantu dalam memudahkan dan memperlancar tugas, pokok dan fungsi dalam jabatannya, mewujudkan efisiensi dan efektivitas kinerja individu serta perbaikan pembangunan dan pelayanan pada masyarakat. Konstruksi para aparat meyakini dan mempercayai bahwa konstruksi para aparat terhadap eksistensi profesionalisme aparat di daerah dianggap akan memberi keuntungan yang besar bagi terwujudnya trust building kelembagaan, akses untuk mendorong percapaian visi dan misi kabupaten atau SKPD serta mampu mempermudah dan memperlancar tugas-tugas pokok harian yang menjadi beban dan kewenangannya serta ada relasi antara profesionalisme itu sendiri dengan sistem pendapatan yang layak.

Konstruksi para aparat terhadap pemberian tambahan tunjangan kinerja, dinilai tidak berdampak pada merosotnya etos kerja maupun rendahnya disiplin pegawai di Kabupaten Bojonegoro. Konstruksi para aparat terhadap mekanisme dalam penempatan dan atau pemindahan jabatan seseorang masih menggunakan dan mempertimbangkan pendekatan the right man in right place, dan tidak didasarkan atas like and dislike, koncoisme atau faktor-faktor politis tertentu. Konstruksi para aparat meyakini dan mempercayai bahwa pendidikan, penyaringan pegawai secara online memiliki relasi dengan pembentukan profesionalisme para pegawai itu sendiri. Konstruksi para aparat meyakini dan mempercayai bahwa profesionalisme pegawai tidak sekedar diukur dari aspek pendidikan, keahlian dan pengalaman yang dimiliki, namun juga menyangkut aspek sifat-sifat intrinsik individu, yakni kejujuran, sopan santun dan etika kerja seseorang. Meskipun demikian, banyaknya pegawai/aparat yang memiliki latar belakang pendidikan tinggi, pengalaman dan ketrampilan, namun masih dipercaya kurang memiliki nilainilai kejujuran dan etos kerja yang baik. Meskipun kepala SKPD dan unsur pimpinan daerah 
(Bupati dan Wakil Bupati) sama-sama diyakini dan dipercaya mampu menggerakan dan mendorong kinerja bawahan, namun justru yang lebih kuat untuk mendorong, memotivasi serta mengarahkan kinerja para karyawan secara lebih baik, bukan dari pimpinan SKPD, namun justru dari unsur pimpinan Daerah yakni Bupati dan Wakil Bupati.

\section{Daftar Pustaka}

Asia Development Bank (2008) Effectiveness of ADB's capacity develepment assistance: How to get institution right. OED-ADB.

Bogdan RC \& Taylor SJ (1975) Introduction to qualitative research method. Canada: Willes \& Sons Inc.

GTZ (2002) Support for decentralization measurement report, Kerjasama GTZ.

Hall J (2008) The American review of public administration assessing local capacity for federal grant-getting. The American Review of Public Administration.

Maconick R (2010) Capacity building supported by the United Nation: Some evaluation and some lesson. United Nation.

Mariana D (2009) Reformasi baru dan paradigma baru administrasi publik di Indonesia. Dalam Falih S \& Bintoro W (ed). Revitalisasi Administrasi Negara: Reformasi Birokrasi dan e-Governence. Yogyakarta: Graha Ilmu.

Otto S (2009) The capacity development results framework: A strategic and result-oriented approach to learning for capacity development. World Bank Institute.

Simister N and Smith R (2010) Monitoring and evaluation capacity building: Is it really that difficult? Praxis Paper No 23. INTRAC (International NGO Training and Research Centre).

Swanson RA and Holton III (2001) Foundation of human resources development. Koehler Publisher, Inc. San Fransisco.

UNDP (1996) Capacity development: Lessons of experience and guiding principles, New York: UNDP. 